\title{
Research on the Application of Network Video Streaming Media in Colleges Badminton Teaching
}

\author{
Changgui $\mathrm{He}^{1, \mathrm{a}}$ \\ ${ }^{1}$ Polytechnic Institute of Jiangxi Science and Technology Normal University, Nanchang, Jiangxi, \\ 330100
}

Keywords: Colleges, Badminton Teaching, Streaming Media Technology, Application

\begin{abstract}
With the rapid development of network technology, the application of network video streaming media to college physical education has become a trend. As a new type of network video streaming media, it has no time and space constraints. The network video streaming media is a traditional teaching mode of teaching methods, the most effective use of network video streaming media. In this paper, the characteristics of network video streaming media, the use of teaching in the teaching of the advantages of the application of the study, and put forward the relevant application recommendations.
\end{abstract}

\section{Introduction}

The use of network video streaming media technology can cause students to learn interest, to achieve both inside and outside the classroom integration, the creation of learning the public platform. College teachers in the process of badminton teaching, the need to use the network video streaming media technology and traditional teaching methods combined with teaching methods in the teaching process to continuously improve their own quality.

\section{The Network Video Streaming Media}

Network video streaming media is a media that uses streaming technology to play video files. Streaming technology has the compression of video, animation and other video files, timely transmission to the network server [1]. The emergence of streaming technology, to the user to watch the video has brought a new experience. Users do not have to wait for all video files to download video, you can watch while downloading in the background, and point to play video software, just a few seconds to start the time you can watch their choice of video files, the rest will automatically download the background.

You can play while downloading the network video streaming media compared to the traditional video media has the following advantages: across the time and space constraints, you can use multimedia teaching anytime, anywhere to improve the enthusiasm of students to learn physical education; students can according to their own The actual needs of the badminton video to find the study, far more efficient than the traditional teaching methods, students will naturally improve the efficiency of learning; use of multimedia teaching, teachers can play in the classroom format video files, not only can enhance Students learn fun, but also can create a good learning atmosphere, so that students learn in the happy, happy in the study.

\section{The use of network video streaming media in teaching}

On the badminton teaching skills in the process, teachers can be published through the micro-public platform, so that students have a certain understanding before learning, reduce the difficulty of learning badminton skills, improve student learning efficiency. The high hair of the skills have the pace of moving the ball when the move, the racket took the seat.

In order to improve the efficiency of students' learning, teachers can also send their own teaching video to Youku and other video players, so that students choose according to their own learning video teaching. This not only can save students 'search time, improve the efficiency of students' 
learning, but also can achieve the targeted teaching content.

The establishment of a special badminton video teaching website [2]. The establishment of video teaching website is a complex and arduous task, teachers, students and badminton enthusiasts to actively cooperate and work together. Use a variety of website construction tools to complete their own tasks, and use a variety of network video resources to improve their own website. For their own college students to provide a good learning site, but also for other badminton enthusiasts to provide targeted learning resources.

Flexible application of network video streaming media technology, combined with the traditional teaching model. Both the use of good network video streaming technology without the advantages of time and space constraints, but also the use of traditional teaching practice. Through the combination of the two, it achieves the highest learning efficiency and promotes the development of college badminton education.

\section{The Application of Network Video Streaming Media Advantage}

Interest is the best motive to promote students to consciously study, is to inspire students to explore the inherent motivation of self-knowledge. Only students have an interest in learning, will not feel that learning is a burden, but a kind of enjoyment. Network video streaming media has an important role in enhancing students' interest in sports learning. Network video streaming media with vivid images, colorful and other characteristics, can quickly attract the attention of students, to achieve a variety of sensory stimulation.

For badminton teaching in the key and difficult, the teacher can use the network video streaming media technology teaching, rather than repeated practice, not only learning inefficient, and will make students feel offensive psychological. Through the slow down or playback of the video, you can let the students see each action details, is conducive to the students in the badminton teaching in the focus and difficulty of understanding and mastery. Students have mastered these actions, will naturally cause their interest in learning, improve their enthusiasm for learning, badminton learning to lay a good foundation.

Today, badminton teaching in colleges and universities is mainly classroom teaching, extracurricular few will have targeted guidance, and most schools only sixteen weeks or eight weeks of physical education. Which also includes a variety of sports learning and testing, badminton teaching hours are few, students can use the class time to improve their skills to play badminton or a bit difficult.

The use of network video streaming media technology teaching, you can cross time and space constraints. In this way, students can also take the initiative to learn the teacher's teaching video. Students learn the process, encounter more complex movements, you can play back or slow down the video speed, after several viewing and practice, students can easily grasp the badminton skills. Moreover, students can according to their own learning needs, watch badminton teaching video, to strengthen the understanding of complex badminton skills, and thus achieve high efficiency teaching effect.

After 90 college students are able to quickly absorb new media crowd, for their interest in things like to share with their friends or talk with their friends. In order to understand the students' learning and improve their interest in learning, badminton teachers can create a learning platform for the public. In the platform, the teacher can communicate with the students anytime, anywhere learning knowledge and status of badminton, and before the teaching activities to carry out their own teaching plan and the teaching task of this lesson published in the study of public platform, so that students in advance of this section of the student content Get to understand. After the end of the course will be the teacher's guidance published in the learning platform, and attach the focus and difficult teaching video. This study can use their own spare time, according to the guidance of teachers to carry out targeted learning. For teachers of classroom teaching, students can also learn the public platform and teachers to exchange their own learning experience, put forward their own suggestions and ideas, teachers can adopt the recommendations of students, to make improvements. The creation of WeChat public learning platform is conducive to teachers and students in the study 
of common progress.

\section{The Network Video Streaming Media Application Recommendations}

The use of network video streaming technology teaching does not mean to give up the traditional sports teaching model. Only the traditional teaching mode and network video streaming media organic combination, in order to better promote the development of college physical education, improve the teaching efficiency of teachers and students learning enthusiasm. The network video streaming media as a supporting means of college badminton teaching, can improve the classroom teaching content, rich teaching methods, and create a good learning atmosphere. Of course, teachers in improving the teaching content and teaching methods at the same time, but also actively on the traditional teaching methods of innovation.

Teachers are badminton teaching courses to teach, teachers of their own quality and low determines the quality of badminton teaching. Teachers of their own high quality, students can be proud of their own, become a model of student learning. In this era of rapid development of network technology, teachers should continue to improve their own quality, follow the development of the times to add their own network of technical knowledge. Can be proficient in the use of network video streaming media technology to carry out teaching activities, master a variety of teaching courseware production methods, combined with their own teaching characteristics to create a unique and effective teaching courseware.

Through the network video streaming technology, although it can be intuitive, vivid and short time to play badminton skills tutorials, but also on the focus and difficult action repeatedly play or slow down the playback speed, but the teaching process should also comply with the body through exercise to produce muscle memory Training rules. Training badminton skills, should be watching the badminton teaching video on the basis of the corresponding training. Focus on the combination of theory and practice, only through continuous practice, students can better grasp their own badminton skills to watch and improve their own badminton skills.

The use of online video streaming media teaching, not only to provide students with a good learning opportunities for teachers is also a self-improvement process, teachers should make full use of this learning opportunities. For those who do not understand or difficult to understand, teachers should take the initiative to communicate with their students, especially the computer professional students in the network application technology can give teachers a great help. Through continuous learning, teachers can learn what they have learned in the teaching process and the learned student learning situation into their own scientific research. The use of network video streaming media technology is in the teaching process to further enhance themselves.

\section{Conclusion}

All in all, the network video streaming technology has an important application value for college badminton teaching. Not only can cause students to learn interest, improve students' learning efficiency, but also for the badminton teachers to provide learning and enhance their own opportunities. Of course, in the use of network video streaming technology at the same time can not ignore the traditional teaching model, should be used in two teaching methods combined teaching methods.

\section{References}

[1] Zhang Xiubo. Network video streaming media in college badminton teaching application research [J]. Sports Science and Technology, 2016, (05): 152-153.

[2] Chen Yisong. The application and implementation of streaming video on demand and retrieval [J]. Computer CD-ROM Software and Application, 2014, (16): 196-197 